\title{
NOTE
}

\section{Role of advection in the distribution and abundance of Pleurobrachia pileus in Kiel Bight}

\author{
Gerald Schneider \\ Institut für Meereskunde an der Universität Kiel, Düsternbrooker Weg 20, D-2300 Kiel, Federal Republic of Germany
}

ABSTRACT: Abundance of the ctenophore Pleurobrachia pileus and salinity were studied at a station in the western Kiel Bight from January to July 1981. Results suggest that variations of the ctenophore stock were primarily caused by advection and did not reflect the biological population cycle of this species.

Kiel Bight and adjacent areas connect the Kattegat with the relatively less saline waters of the Baltic proper. Strong oscillations in the hydrographic conditions of this transition area occur due to the prevailing wind regime and the annual river runoff pattern (summarized by Lenz 1977a). The advection of either Kattegat or Baltic water into Kiel Bight can be monitored comparatively easily by studying changes in salinity (Kändler \& Wattenberg 1940, Wattenberg 1949).

Such hydrographic variations make biological investigations complex, because polyhaline and mesohaline waters exhibit different plankton populations (Lenz $1977 \mathrm{~b}$ ) so plankton studies at a fixed station are affected by horizontal water movements. Such movements are most pronounced in Kiel Bight from spring to autumn (Lenz 1981). Advective processes may, on the one hand, transport plankton species into Kiel Bight which do not normally occur in this area ('indicator species'; Kändler \& Wattenberg 1940) and, on the other hand, induce variation in abundance of indigenous species if generation times are greater than the residence time of the water in Kiel Bight. These variations cannot be explained by reproduction and mortality rates. Therefore, a closer look at the role of horizontal water movements on planktological studies is needed. The aim of this note is to demonstrate the effect of advection on the abundance of the ctenophore Pleurobrachia pileus during the first half of 1981.

The investigation was carried out between January and July 1981 inclusive at the 'Boknis Eck' station in the western Kiel Bight (Fig. 1). Water depth at the station was 26 to $27 \mathrm{~m}$, and samples were taken every 2 wk. Ctenophores were collected with a 'Helgoländer Larvennetz' (diameter $1 \mathrm{~m}, 300 \mu \mathrm{m}$ mesh) by vertical hauls from about $2 \mathrm{~m}$ above the sea bottom to the surface. Individuals were counted alive in the laboratory and their diameters measured. For younger stages a dissecting microscope was used. Hydrographic conditions were recorded using an Electronic Switchgear TS-Probe.

During winter, water was well mixed, with salinity values close to $20 \%$ (Fig. 2). Due to advection of Baltic waters in spring, salinity decreased to minimum values at the end of April. This is a regular annual event (summarized by Babenerd 1980, 1986) caused by increase of river discharge due to melting snow and ice (Brogmus 1952) and increase of easterly winds (Schweimer 1978). In contrast, the summer situation is characterized by a well-developed halocline and salin-

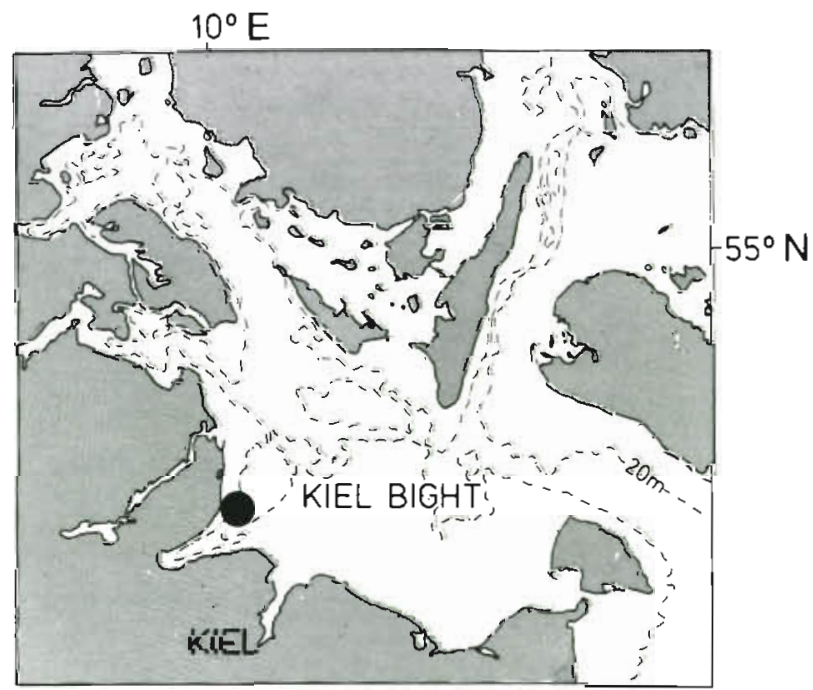

Fig. 1. Kiel Bight with the 'Boknis Eck' station indicated by a dot 


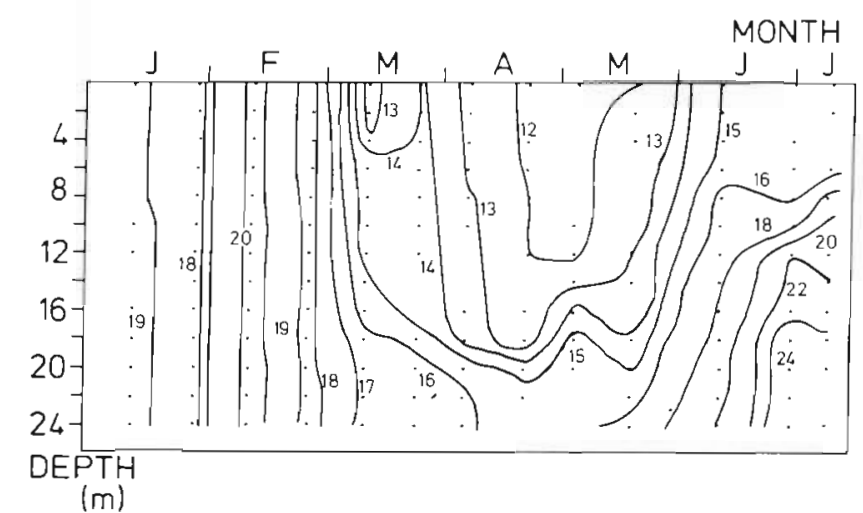

Fig. 2. Seasonal course of salinity (\%) at 'Boknis Eck', January to July 1981

ity values up to $24 \%$ in the deeper layers. Westerly winds predominate during this season (Schweimer 1978) leading to an influx of higher salinity Kattegat waters into Kiel Bight, forming the near-bottom layers.

Abundance of Pleurobrachia pileus was low in 1981; the highest value recorded was 55 ind $100 \mathrm{~m}^{-3}$. In spring values dropped to zero, but in summer a repopulation occured (Fig. 3). Cruises to 3 other localities in the Kiel Bight substantiated the abundance pattern obtained at 'Boknis Eck' (Schneider 1981). Larvae and very young juveniles were not observed at any time during the investigation. The diameter of all individuals caught ranged from 5 to $15 \mathrm{~mm}$ in winter and spring and from 10 to $18 \mathrm{~mm}$ in summer.The averaged salinity $(\bar{S})$ of the water column and abundance $(A)$ of the ctenophores are significantly correlated:

$$
\begin{gathered}
\mathrm{A}=5.18 \overline{\mathrm{S}}-64.8 \\
I=0.849, \mathrm{n}=13, \mathrm{p}<0.001 .
\end{gathered}
$$

It seems that the fluctuations in abundance which coincided with those in salinity were caused by advective processes and predominately reflect the different ctenophore loads in the water masses. In Kiel Bight $P$. pileus reaches its maximal population density in autumn and winter and the decline of the stock in spring has been noted by many investigators (Möbius 1873, Krumbach 1926, Kändler 1961, Hillebrandt 1972, Lenz 1973). The disappearance in spring cannot be explained by predation or any other factor leading to mortality. We know that ctenophores of the genus Beroe, some scyphozoan medusae, the pelagic polychaete Tomopteris and some species of fish prey on $P$. pileus (Cargo \& Schultz 1967, Fraser 1970, Greve 1972,1977 ), but these animals do not occur in Kiel Bight in early spring. Infestation with parasites (e.g. Greve 1969) was not observed during this investigation, food limitation seems to be improbable due to low ctenophore abundance, and changes of temperature and salinity were well within the ecophysiological
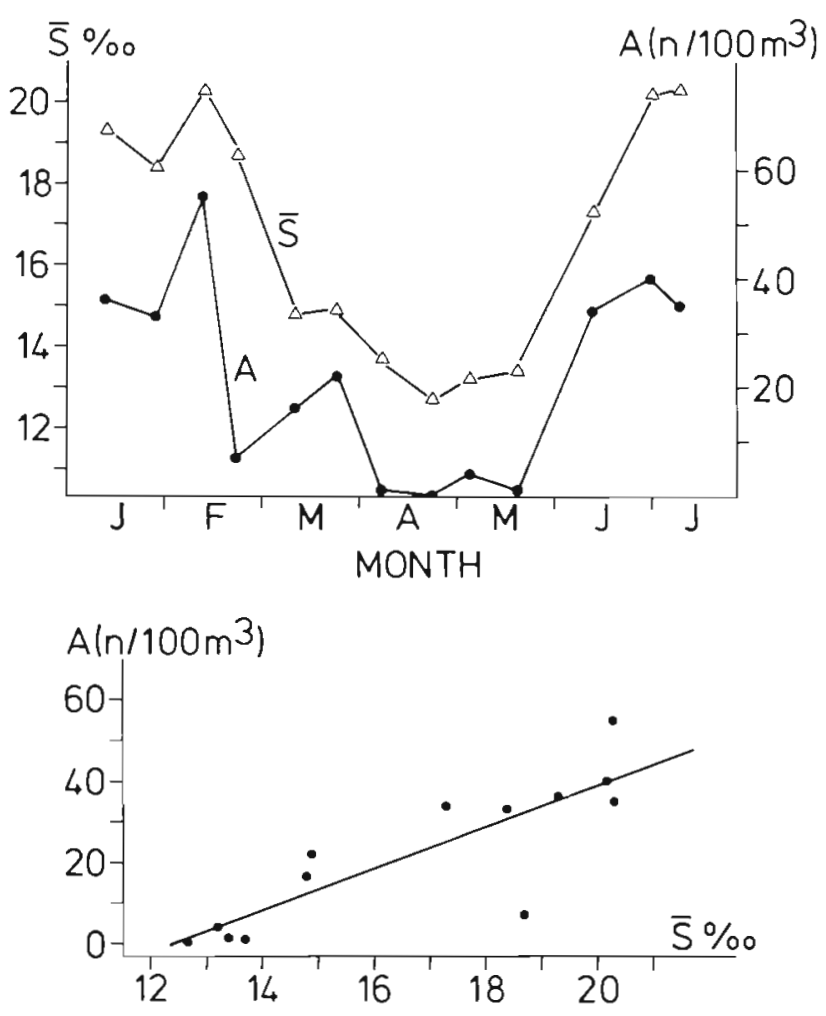

Fig. 3. Above: abundance (A) of Pleurobrachia pileus and averaged salinity $(\overline{\mathrm{S}})$ for the $24 \mathrm{~m}$ water column. Below: abundance $(A)$ versus averaged salinity $(\bar{S})$

range of this species (Greve 1972). This situation is similar to that described by Deason \& Smayda (1982), where a lobate species, Mnemiopsis leidyi, disappeared from Narragansett Bay plankton for no apparent reason. However, the process of advection may explain the decrease in $P$. pileus abundance in spring. This species is found in the Baltic up to the Finnish coast, but only occurs at depths greater than $40 \mathrm{~m}$ (Mielck 1926, Mielck \& Künne 1935) due to the socalled brackish water submergence (Remane 1940). The annual outflow of low salinity Baltic waters in spring, however, is restricted only to surface layers, and no individuals of the Baltic $P$. pileus stock will be transported into Kiel Bight by this process. Therefore, the water masses entenng the Kiel Bight in spring are devoid of ctenophores and it can be suggested that the ctenophore stock developing in autumn and winter is flushed out in spring northwards to the Belt Sea area and southern Kattegat.

It is possible that a part of the ctenophore population migrated to the near-bottom water layers, thus accumulating below the deepest position of the net's mouth. An underestimation of the ctenophore stock and a higher predation pressure by benthic animals such as Metridium senile, Carcinus maenas or Eupagurus bernhardus would result (Greve 1972). However, 
plankton hauls by Fahlteich (1981) taken $0.5 \mathrm{~m}$ above the sea bed at the same station and time revealed no evidence for any higher near-bottom density.

In contrast to early spring, there is strong evidence that the observed repopulation by Pleurobrachia pileus in early summer (Fig. 3) is caused by the advection of high salinity but ctenophore-rich waters from the Belt Sea area and the Kattegat. Firstly, Driver (1908) and Kramp $(1913,1915)$ showed that P. pileus reaches its maximal population density in the Belt Sea in May or June, which means that the potential for transport of ctenophores into Kiel Bight from this region is best in early summer. Secondly, long-term data collected by our department from 1957 to 1975 suggest inflow of waters from the Belt Sea area in summer to be a regular annual event (Babenerd 1980). This inflow is also indicated by the salinity data presented for 1981. From this, it seems reasonable to explain the sharp increase of $P$. pileus abundance in June 1981 by the advection hypothesis given above.

As an alternative hypothesis it might be argued that some winter specimens survived in near-bottom water layers and reproduced there, and the coarse mesh size of the net used did not retain the youngest stages which are only $100 \mu \mathrm{m}$ in diameter. However, the absence of individuals smaller than $10 \mathrm{~mm}$ and the observations by Remane (1956) and Kändler (1961) that Pleurobrachia pileus larvae appear in Kiel Bight plankton only in autumn tend to support the advection hypothesis. Moreover, if some reproduction occurs the youngest stages will have heavy mortality. Greve (1972) described how young ctenophores are destroyed by adult copepods. This is important because the seasonal plankton cycle in the Kiel Bight exhibits a pronounced copepod peak in late spring (summarized by Smetacek 1985). In addition, the scyphomedusae Aurelia aurita shows its maximal growth period in late spring (Möller 1980, Schneider unpubl.) which may also lead to high mortality in $P$. pileus larvae. Overall, it seems that advection was the dominant factor governing the abundance of $P$. pileus in the January to July period 1981. To distinguish between succession and sequence, the role of advection has to be considered in all Kiel Bight plankton studies, and in estuaries and semienclosed bays with similar circulation patterns. The importance of advection in the Kiel Bight has also been stressed by Banse $(1956,1959)$ and Kändler (1961). Annual differences and seasonal fluctuations of zooplankton standing stock in this highly dynamic transition area should therefore also be discussed in this context.

Acknowledgements. I thank Professor Dr J. Lenz, 3 anonymous referees and $\mathrm{Mr} \mathrm{R}$. Wilson for their valuable criticism of an earlier version of this paper and for help in preparing the English text.

\section{LITERATURE CITED}

Babenerd, B. (1980). Untersuchungen zur Produktionsbiologie des Planktons in der Kieler Bucht mit einer Auswertung der monatlichen Terminfahrten aus den Jahren 1957 bis 1975. Dissertation, Univ. Kiel

Babenerd, B. (1986). Long-term observations of some hydrographical, chemical, and planktological variables in Kiel Bay, 1957-1975. Coun. Meet. int. Coun. Explor. Sea C.M. ICES 1986/L: 19

Banse, K. (1956). Über den Transport von meroplanktischen Larven aus dem Kattegat in die Kieler Bucht. Ber. dt. wiss. Kommn Meeresforsch. 14: 147-164

Banse, K. (1959). Die Vertikalverteilung planktischer Copepoden in der Kieler Bucht. Ber. dt. wiss. Kommn Meeresforsch. 15: $357-390$

Brogmus, W. (1952). Eine Revision des Wasserhaushaltes der Ostsee. Kieler Meeresforsch. 9: 15-42

Cargo, D. G., Schultz, L. P. (1967). Further observations on the biology of the sea nettle and jellyfishes in Chesapeake Bay. Chesapeake Sci. 8: 209-220

Deason, E. E., Smayda, T. J. (1982). Ctenophore-zooplankton - phytoplankton interactions in Marragansett Bay, Rhode Island, USA, during 1972-1977. J. Plankton Res. 4: 203-217

Driver, H. (1908). Das Ostseeplankton der 4 deutschen Terminfahrten im Jahre 1905. Wiss. Meeresunters., Abt. Kiel, N.F. 10: 109-128

Fahlteich, E. (1981). Zur Frühjahrsentwicklung der Copepoden in der Kieler Bucht. MS thesis, Univ. Kiel

Fraser, J. H. (1970). The ecology of the ctenophore Pleurobrachia pileus in Scotish waters. J. Cons. int. Explor. Mer 33: $149-168$

Greve, W. (1969). Zur Ökologie der Ctenophore Pleurobrachia pileus. Dissertation, Univ. Kiel

Greve, W. (1972). Ökologische Untersuchungen an Pleurobrachia pileus. 2. Laboratoriumsuntersuchungen. Helgoländer wiss. Meeresunters. 23: 141-164

Greve, W. (1977). Interspecific interaction: the analysis of complex structures in carnivorous zooplankton populations. Helgoländer wiss. Meeresunters. 30: 83-91

Hillebrandt, M. (1972). Untersuchungen über die qualitative und quantitative Zusammensetzung des Zooplanktons in der Kieler Bucht während der Jahre 1966-1968. Dissertation, Univ. Kiel

Kändler, R. (1961). Über das Vorkommen von Fischbrut, Dekapodenlarven und Medusen in der Kieler Förde. Kieler Meeresforsch. 17: 48-64

Kändler, R., Wattenberg, H. (1940). Einige Ergebnisse der Untersuchungsfahrten mit dem Reichsforschungsdampfer "Poseidon" in der westlichen Ostsee 1938. Ber. dt. wiss. Komm. Meeresforsch. 9: 541-560

Kramp, P. L. (1913). Coelenterata. Bull. trimest. Résult. Crois. périod. Cons. perm. int. Explor. Mer 3: 522-538

Kramp, P. L. (1915). Medusae, ctenophora and chaetognathi from the the Great Belt and the Kattegat in 1909. Medd. Komm. Havundersøgelser, Serie Plankton, Bind 1, No. 12 : 3-20

Krumbach, T. (1926). Ctenophora. In: Grimpe, G., Wagler, E. (ed.) Die Tierwelt der Nord- und Ostsee. Akademische Verlagsgesellschaft Becker \& Erler, Leipzig, p. 1-50

Lenz, J. (1973). On the occurence of the ctenophore Bolinopsis infundibulum (O. F. Müller) in the Western Baltic. J. Cons. int. Explor. Mer 35: 32-35

Lenz, J. (1977a). Hydrographic conditions. In: Rheinheimer, G. (ed.) Microbial ecology of a brackish water environment. Springer-Verlag, Berlin, p. 12-25 
Lenz, J. (1977b). Plankton populations. In: Rheinheimer, G. (ed.) Microbial ecology of a brackish water environment. Springer-Verlag, Berlin, p. 79-89

Lenz, J. (1981). Phytoplankton standing stock and primary production in the Western Baltic. In: Rheinheimer, G., Flügel, F., Lenz, J., Zeitzschel, B. (ed.) Lower organisms and their role in the food web. Kieler Meeresforsch. Sonderh. 5: $29-40$

Mielck, W. (1926). Die Verbreitung der größeren Planktontiere in der Ostsee, April 1925. Ber. dt. wiss. Kommn Meeresforsch. 2: 299-303

Mielck, W., Künne, C. (1935). Fischbrut- und Plankton-Untersuchungen auf dem Reichsforschungsdampfer "Poseidon" in der Ostsee, Mai-Juni 1931. Helgoländer wiss. Meeresunters. 19: 1-119

Möbius, K. (1873). Die Wirbellosen Tiere der Ostsee. Jahresbericht der Commission zur wiss. Untersuchung der deutschen Meere in Kiel I: 97-144

Möller, H. (1980). Population dynamics of Aurelia aurita medusae in Kiel Bight, Germany (FRG). Mar, Biol. 60: 123-128

Remane, A. (1940). Einführung in die zoologische Ökologie der Nord- und Ostsee. In: Grimpe, G. Wagler, E. (ed.) Die Tierwelt der Nord- und Ostsee. Akademische Verlagsgesellschaft Becker \& Erler, Leipzig, p. 1-238

Remane, A. (1956). Zur Biologie des Jugendstadiums der Ctenophore Pleurobrachia pileus (O. F. Müller). Kieler Meeresforsch. 12: 72-75

Schneider, G. (1981). Untersuchungen zum Vorkommen und zur Ökologie von Ctenophoren in der Kieler Bucht. MS thesis, Univ. Kiel

Schweimer, M. (1978). Physikalisch - ozeanographische Parameter in der westlichen Ostsee - eine Literaturstudie -. Ber. Inst. Meeresk. Univ. Kiel Nr. 61: 1-139

Smetacek, V. (1985). The annual cycle of Kiel Bight plankton: a long-term analysis. Estuaries 8: 145-157

Wattenberg. H. (1949). Die Salzgehaltsverteilung in der Kieler Bucht und ihre Abhängigkeit von Strom- und Wetterlage. Kieler Meeresforsch. 6: 17-30

This note was submitted to the editor; it was accepted for printing on August 26, 1987 